\title{
Parkinsono liga ir kiti judejjimo sutrikimai SARS-CoV-2 sukeltos pandemijos kontekste
}

\author{
R. Kaladytė Lokominienė \\ Vilniaus universitetas, \\ Neurologijos centras
}

\begin{abstract}
Santrauka. Antro tipo sunkų ūminį kvėpavimo takų pažeidimo sindromą sukeliantis koronavirusas (SARS-CoV-2) gali pažeisti žmogaus nervų sistemą ir sąlygoti galvos skausmą, pykinimą, vėmimą, febrilinius traukulius, encefalopatiją, encefalitą, ataksiją ar psichikos sutrikimus, taip pat kiekybinius uoslès ir skonio pakitimus, kurie būdingi ir Parkinsono ligai (PL) bei kitoms alfa sinukleinopatijoms, tik progresuoja lètai ir būna negrịžtami. SARS-CoV-2 penetravus ị PL pažeistas galvos smegenis, gali pasunkèti klinikiniai judẻjimo ligos simptomai ir padidèti pakaitinès dopaminerginės terapijos poreikis. PL ar kitais judėjimo sutrikimais sergančių asmenų COVID-19 padarinius vertinančių atsitiktinių imčiu tyrimų kol kas nèra, tačiau šios grupès asmenys galètų būti stipriau pažeidžiami dẻl kvẻpavime dalyvaujančių raumenų rigidiškumo ar dissinergijos, silpnesnio kosulio reflekso, sutrikusio rijimo, lètinės ligos sukelto dusulio. Netiesioginiai veiksniai, kylantys pandemijos metu, stresas, saviizoliacija, nerimas, ilgalaikis hipomobilumas, sunkina judèjimo sutrikimo klinikines išraiškas ir predisponuoja silpnesnes imunines reakcijas ị infekcijas. Dẻl ribotų kontaktų su medikais ir artimaisiais kognityvinių sutrikimų turintys pacientai gali dažniau pažeisti vaistų vartojimo režimą, todèl teleneurologija yra perspektyvi pagalba judèjimo sutrikimų turinčiam pacientui pandemijos metu. Yra prielaidų, kad amantadinas ir memantinas galètų pasižymėti anti-SARS-CoV-2 potencialu, tačiau reikalingi klinikiniai tyrimai. Tarptautinè Parkinsono ligos ir judejjimo sutrikimų draugija pateikè rekomendacijas sergantiesiems Parkinsono liga ir kitais judejjimo sutrikimais COVID-19 pandemijos metu, kur nurodẻ griežtai laikytis bendrai populiacijai taikomų socialinių kontaktų ribojimo priemonių, tiesiogiai apžiūrèti pacientą tik išimties atveju (pvz., norint koreguoti giliųjų pamato branduolių stimuliatoriaus programą ar bateriją, duodenalinès levodopos pompos veiklą, atlikti būtinas botulino toksino injekcijas), skatinti pacientus naudoti namuose prieinamas sporto priemones ar (ir) žaisti virtualios realybės žaidimus. Diagnozavus COVID-19, gydytojas turi užtikrinti tolesnị anksčiau judejjimo sutrikimui gydyti skirtų vaistų vartojimą (ypač adekvačias levodopos ir periferinės dekarboksilazès inhibitoriaus dozes), kad būtų išvengta sustiprèjusio rigidiškumo, kontraktūrų, gyvybinès plaučių talpos ir maksimalaus iškvejpimo tūrio sumažèjimo.
\end{abstract}

Raktažodžiai: Parkinsono liga, judejjimo sutrikimai, SARS-CoV-2, pandemija, COVID-19.

\author{
Adresas: \\ Rūta Kaladytè Lokominienè \\ Vilniaus universiteto ligonine Santaros klinikos, \\ Neurologijos centras \\ Santariškiu g. 2, LT-08661 Vilnius \\ El.paštas ruta.kaladyte-lokominiene@santa.lt
}

\section{KORONAVIRUSU INFEKCIJOS IR NEURODEGENERACINIŲ LIGŲ PATOGENEZĖS SĄSAJOS}

Žmogaus koronaviruso ligos dažniausiai pasireiškia lengvais kvėpavimo takų ligų simptomais. XXI a. jau įvyko du naujų koronaviruso infekcijų proveržiai, kurių metu buvo stebimi sunkūs kvėpavimo takų ir ịvairių organizmo sistemų klinikiniai pažeidimai bei didelis mirtingumas. Tai 2002 m. sunkų ūminị kvẻpavimo takų pažeidimo sindromą sukeliančio koronaviruso (angl. severe acute respira-

(C) Neurologijos seminarai, 2020. Open Access. This article is distributed under the terms of the Creative Commons Attribution 4.0 International License CC-BY 4.0 (http://creativecommons.org/licenses/by/4.0/), which permits unrestricted use, distribution, and reproduction in any medium, provided you give appropriate credit to the original author(s) and the source, provide a link to the Creative Commons license, and indicate if changes were made. 
tory syndrome coronavirus, SARS-CoV) ir $2012 \mathrm{~m}$. Artimųjų Rytų kvėpavimo takų pažeidimo sindromą sukeliančio koronaviruso (angl. Middle East respiratory syndrome coronavirus, MERS-CoV) epidemijos. Dabartinès COVID-19 pandemijos priežastis yra SARS-CoV-2 - antro tipo sunkų ūminị kvèpavimo takų pažeidimo sindromą sukeliantis koronavirusas (angl. severe acute respiratory syndrome coronavirus-2), užregistruotas Kinijoje 2019 m. pabaigoje ir šiuo metu paplitęs po visą pasauli. Koronavirusų, kurie pasižymi neurotropizmu ir neuroinvaziniais gebėjimais, infekcijos žmogui gali sukelti net tik kvèpavimo, bet ir nervų sistemos pažeidimą, pavyzdžiui, galvos skausmą, pykinimą ir vėmimą, febrilinius traukulius, encefalopatiją, encefalitą, psichikos sutrikimus [1-4], nors duomenų apie simptomų dažnị ir spektrą vis dar labai nedaug. Irano mokslininkai A. A. Asadi-Pooya ir L. Simani atliko sisteminę literatūros apžvalgą, norėdami apibendrinti CNS pažeidimo simptomus COVID-19 metu - išnagrinèjo 1655 straipsnius [1]. Dažniausiai literatūros šaltiniuose apibendrintai buvo apžvelgiama klinikinė COVID-19 simptomatika, straipsniai skelbiami po supaprastintos redagavimo procedūros elektroniniu variantu prieš spausdinimą ir tik dviejuose iš jų specifiškai tebuvo nagrinėjamas neurologinis pažeidimas, bet nė viename plačiau neaprašyti smegenų skysčio tyrimo ir elektroencefalografijos rezultatai [1]. Vienas straipsnis buvo diskusijos pobūdžio, o kitame pateikti Kinijoje atliktos retrospektyvios klinikinių atvejų analizès rezultatai: L. Mao su kolegomis išnagrinèjo Uhane hospitalizuotų COVID-19 pacientų neurologinius simptomus ir nustatè, kad juos patyrè $25 \%$ pacientų [4]: dažniau pasitaikè svaigimas $(17 \%)$, galvos skausmas (13\%), sąmonès sutrikimai $(8 \%)$, rečiau - galvos smegenų kraujotakos sutrikimai $(3 \%)$, traukuliai $(0,5 \%)$ ir ataksija $(0,5 \%)$. Kituose tyrimuose neurologinio pažeidimo ivertinimas nebuvo svarbiausias uždavinys, bet buvo aprašyti panašūs įvairaus dažnio nervų sistemos simptomai. Klasikiniai ekstrapiramidinès sistemos pažeidimo sindromai nebuvo paminèti tarp šios virusinès infekcijos sukeltų klinikinių reiškinių.

Vis dèlto, kai kurie ankstesni mokslininkų pastebejjimai šiandieniame kontekste leidžia gana intriguojančiai susieti koronavirusus ir neurodegeneracines ligas. Daugiau kaip prieš $25 \mathrm{~m}$. E. Fazzini su bendraautoriais nustate Parkinsono liga (PL) sergančių asmenų smegenų skystyje reikšmingai didesnius kiekius antikūnų prieš koronavirusus, nei kontroliniams sveikiems ir kitomis ligomis sergantiems tiriamiesiems, ir iškèlè hipotezę, kad šios grupès virusai gali turèti reikšmės su PL susijusio degeneracinio proceso patogenezei [5]. Tačiau pastaraisiais dešimtmečiais, atsižvelgdami ị prielaidas, kad PL patomorfologiniai pakitimai anksčiausiai prasideda enterinejje nervų sistemoje, alfa sinukleinopatijų ir kitų judejjimo sutrikimų evoliucijos tyrèjai skyrė daugiau dėmesio žarnyno mikrobiomui ir tokiems patogenams, kaip H. pylori, enterobakterijoms, cianobakterijoms. Būtent COVID-19 pandemija privertè visus skirtingų biomedicinos mokslų sričių teoretikus ir praktikus sutelkti jègas kovoje su
SARS-CoV-2, kuo greičiau išnagrinèti šio viruso ir jo sukeliamos žmogaus organizmo invazijos ypatumus, sugretinti eksperimentuose ir tyrimuose igytas žinias su anksčiau sukaupta patirtimi bei pastebejjimais ir persvarstyti atraminius teiginius. Žinoma, kad MERS-CoV ir SARS-CoV-2 patenka i galvos smegenis per nosies ertmès respiracini epiteli ir olfaktorinius nervus. Eksperimentiniuose pelių modeliuose šie virusai po inokuliacijos i olfaktorinius nervus buvo aptikti būtent galvos smegenyse, bet ne plaučiuose. Klinikiniai stebėjimai demonstruoja, kad SARS-CoV-2 invazija daugeliui pacientų sukelia ūminę hiposmiją ar anosmiją ir disgeuziją, hipogeuziją ar net ageuziją. Daugiacentriniame Europos šalių tyrime, kuriame dalyvavo 12 ligoninių gydyti 417 pacientu su patvirtinta lengva ar vidutinio sunkumo COVID-19 forma, nustatyta, kad dažniausiai patiriami bendri simptomai buvo kosulys, mialgija, anoreksija, o su liga susiję veido skausmas, nosies užgulimas ir uoslès $(85,6 \%)$ bei skonio $(88 \%)$ sutrikimai $(\mathrm{p}<0,001)$, dažniau moterims $(p=0,001)$ [6]. Šio tyrimo duomenimis, uoslès disfunkcija atsirado anksčiau už kitus požymius $11,8 \%$ atvejų ir nebūtinai buvo susijusi su nosies užgulimu ar sekrecija: 18,2 \% tiriamųjų nepatyrè nei nosies užgulimo, nei rinorejos, tačiau 79,7 \% iš jų buvo hiposmija ar anosmija. Staiga atsiradę uoslès ir skonio sutrikimai greitai atsistatė $44 \%$ pacientų, sirgusių patvirtintu COVID-19 [6]. Kiekybiniai uoslès ir skonio pakitimai yra būdingi ir PL bei kitoms alfa sinukleinopatijoms (daugiasistemei degeneracijai, demencijai su Lewy kūneliais) ir gali vystytis dar premotorineje stadijoje, tik paprastai progresuoja daug lèčiau nei ūminès SARS-CoV-2 infekcijos metu ir būna negrị̌ztami [7].

SARS-CoV-2 invazija vyksta viruso karūnos glikoproteinui prisijungus prie angiotenziną konvertuojančio fermento 2 (angl. angiotensin-converting enzyme 2, ACE2) receptorių. Šie receptoriai yra gausiai ekspresuojami įvairiose ląstelèse: plaučių antro tipo alveolinėse ląstelèse, plonụjų žarnų enterocituose, arterijų ir venų endoteliocituose, daugelio organų arterijų lygiųjų raumenų ląstelèse, taip pat ir normaliuose dopaminerginiuose neuronuose. ACE2 mRNR ekspresuojama ir galvos smegenų žievejje, dryžuotame kūne, pagumburyje ir smegenų kamiene. PL būdingo degeneracinio proceso metu ACE2 receptorių kiekis dopaminerginiuose neuronuose labai sumažèja. MPTP sukelto parkinsonizmo eksperimentiniuose modeliuose įrodyta, kad smegenų angiotenzinas yra svarbus uždegiminio proceso reguliacijai ir, tikètina, neurodegeneracinio proceso progresavimo kontrolei [8]. Taigi, SARS-CoV-2 penetravus į PL pažeistas galvos smegenis ir užblokavus ACE2 receptorius, gali pasunkėti klinikiniai judẻjimo ligos simptomai ir padidèti pakaitinès dopaminerginès terapijos poreikis. Šią prielaidą patvirtina ir aktualūs klinikiniai pastebėjimai [9]. Galiausiai, dopamino sintezès kelias galimai yra svarbus ir COVID-19 patofiziologijai, nes ACE2 ir dopamino dekarboksilazei būdinga bendra ekspresija ir reguliacija kitose, nei neurono tipo, ląstelèse, taigi SARS-CoV-2 potencialiai gali sukelti ar didinti esamą dopamino stoką [10]. 


\section{SARS-COV-2 POVEIKIS LĖTINE NEUROLOGINE LIGA SU JUDESIŲ SUTRIKIMAIS SERGANČIAM PACIENTUI}

Literatūros šaltiniuose ir realiame gyvenime šiandien ypač aktyviai vyksta diskusijos dèl neurologinių COVID-19 pasekmių ir poveikio įvairiomis kitomis bei lètinèmis ligomis sergantiems asmenims, nėščiosioms, vaikams ir imunosupresuotiems asmenims. Nors apie 80 \% SARS-CoV-2 infekuotų asmenų serga lengvai ir pasveiksta be komplikacijų, tačiau iki $5 \%$ tenka taikyti intensyviają terapiją dèl plaučių uždegimo ar ūminio kvėpavimo distreso sindromo. Panašu, kad SARS-COV-2 infekcijos išeitys, kai pacientai buvo vyresni nei $50 \mathrm{~m}$. ir sirgo létinemis ligomis (ypač kardiovaskulinėmis, plaučių, inkstų, diabetu), buvo sunkesnès [1-3]. Pažengusia PL ar parkinsonizmo sindromais, Hantingtono liga, Vilsono liga, generalizuotomis distonijomis, komplikuotomis ataksijomis sergantys asmenys patenka į padidintos rizikos grupę ir galètų būti stipriau pažeidžiami dẻl kvẻpavime dalyvaujančių raumenų rigidiškumo ar dissinergijos, silpnesnio kosulio reflekso, sutrikusio rijimo ir padidintos aspiracijos rizikos, lètinès ligos sukelto dusulio [11], taip pat dèl viruso neurotropizmo. Netiesioginiai veiksniai, kylantys pandemijos metu, - stresas, saviizoliacija, nerimas, ilgalaikis hipomobilumas, sunkina judejjimo sutrikimo klinikines išraiškas ir predisponuoja silpnesnes imunines reakcijas ị infekcijas [12, 13]. Dėl ribotų kontaktų su medikais ir artimaisiais kognityvinių sutrikimų turintys pacientai gali dažniau pažeisti vaistų vartojimo režimą. PL ar kitais judèjimo sutrikimais sergančių asmenų SARS-COV-2 sukeltos infekcijos padarinius vertinančių randomizuotų tyrimų nėra. Šiuo metu literatūros šaltiniuose galime aptikti tik klinikinių atvejų aprašymų. Padujos universiteto ir Londono karališkojo koledžo mokslininkai apibendrino stebėtų Parkinsono liga sergančių pacientų COVID-19 išeitis [9]. Iš aprašytų 10 pacientų visi buvo vyresni nei $60 \mathrm{~m}$. (61-94 m., vidutinis amžius 78,3 m.), sirgo pažengusia PL (vidutinè ligos trukmè $12,7 \mathrm{~m}$.), vartojo levodopos (monoterapijai arba pridètinei terapijai) ir turejjo lydinčių ligų (koronarinę širdies ligą, širdies nepakankamumą, cukrinị diabetą, sąnarių, inkstų ligų, įvairios kilmès demenciją). Viena iš svarbiausių tyrimo išvadų - visiems pacientams COVID-19 metu dèl pasunkèjusios motorinès būklès teko padidinti levodopos dozę (oraliniu arba duodenalinio gelio pavidalu). Jiems taip pat sustiprejo nerimas, nuovargis, ortostatinè hipotenzija, pasunkejjo kognityvinè būklè, vystėsi psichozè. $40 \%$ pacientų mirè nuo COVID-19 sukeltos pneumonijos, $20 \%$ visiškai pasveiko ir išvyko ị namus, o kiti pacientai po ūminio laikotarpio buvo nukreipti reabilitaciniam gydymui. Blogos išeities rizikos veiksniai - vyresnis amžius, ilgesnis PL stažas, sunkesnė paciento premorbidinè būklè pagal vieningą PL vertinimo skalę, interkurentinès ligos. Labiau pažeidžiami SARS-CoV-2 metu buvo pacientai, kuriems taikoma giliųjų pamato branduolių stimuliacija ir duodenalinẻ levodopos infuzija (jų mirtingumas nuo COVID-19 siekẻ $50 \%$ ), tačiau šie gydymo būdai ir yra taikomi labiau pa- žengusia ir sunkesne PL sergantiems asmenims. Remiantis šio nedidelio tyrimo rezultatais, hospitalizuotų dèl COVID-19 asmenų, sirgusių PL, mirtingumas buvo didesnis nei hospitalizuotų bendro srauto COVID-19 sergančių pacientų, nepaisant skirtingų šalių tyrimų rezultatų heterogeniškumo: vidutinis bendras mirtingumas nuo COVID-19 siekia apie $4 \%$, tarp 65-84 m. asmenų svyruoja nuo 3 iki $11 \%$, o tarp vyresnių - 10-27 \% [14, 15]. S. Richardson su kolegomis Niujorko mieste (JAV) atlikto tyrimo duomenimis, iš 5700 dẻl COVID-19 hospitalizuotų pacientų tyrimo metu buvo išrašyti arba mirè 2634 asmenys; iš jų 14,2 \% buvo gydomi intensyviosios terapijos skyriuje, 12,2 \% taikyta invazinè plaučių ventiliacija, 3,2 \% - hemodializè, o $21 \%$ mirè. Dažniausios lydinčios ligos tarp tyrime dalyvavusių niujorkiečių buvo hipertenzija, nutukimas ir diabetas [14]. Hubejjaus provincijoje (Kinija) iš 1590 hospitalizuotų dèl COVID-19 pacientų $16 \%$ sudarè sunkūs klinikiniai atvejai, o 3,2 \% ligonių mirė [15]. Peržvelgę A. Antonini ir R. Chaudhuri su kolegomis straipsnyje [9] nurodytus COVID-19 susirgusių pacientų vartotus vaistus nuo PL, galime pastebėti ịdomų faktą: kartu su levodopa buvo vartota monoaminooksidazès B inhibitorių (rasagilino, safinamido), dopamino agonistų (ropinirolio, rotigotino), katecholoksitransferazès inhibitoriaus opikapono, tačiau nè vienas ligonis nebuvo gydytas amantadinu ir memantinu, nors šie preparatai pažengusios PL metu skiriami gana dažnai: amantadino svarbiausia indikacija - diskinezijos, savo ruožtu memantino demencijos gydymas. Nors tyrimo autoriai apie tai neužsimena, šis faktas atkreipia dėmesị ir verčia susimąstyti apie $\mathrm{N}$-metil-d-aspartato receptorius blokuojančių adamantano derivatų (amantadino ir memantino) galimai priešvirusines savybes, saugant nuo SARS-CoV-2 sukeliamos infekcijos. Žinoma, italų ir britų tyrimo svarbiausias ribotumas - maža imtis, keltas tikslas - COVID-19 išeičių ir specifinių rizikos veiksnių, susijusių su PL, įvertinimas, o vartotų vaistų analizė labiau sutelkta ị levodopos dozę, tačiau per pastaruosius 4 pandemijos mėnesius dar nèra paskelbta didesnès apimties specializuotų judejjimo sutrikimais sergančių asmenų COVID-19 išeičių tyrimų rezultatų.

\section{VAISTŲ, SKIRIAMŲ JUDE்JIMO SUTRIKIMAMS GYDYTI, ANTI-SARS-COV-2 POTENCIALO TYRIMAI}

Nors COVID-19 tapo pandemija ir ịvairių šalių mokslininkai ieško būdų užkirsti šiai ligai kelią, kol kas specifinių gydymo ir prevencijos priemonių nėra. Pastarųjų mėnesių klinikiniuose tyrimuose daugiausiai dèmesio skiriama prieš žmogaus imunodeficito virusą (lopinaviras, ritonaviras), prieš gripo (favipiraviras) ir kitus virusus (Ebolos, Marburgo, galimai MERS, SARS ir kt. - remdesiviras) sukurtų preparatų efektyvumui, taip pat chlorokvinui ir hidroksichlorokvinui, interferonui beta (Cao ir kt., 2020; Dong ir kt., 2020; Touret ir de Lamballerie, 2020). Japonijos nacionalinio infekcinių ligų instituto mokslininkai, 
remdamiesi literatūros duomenimis, atrinko 306 vaistus ir ištyrè jų gebėjimą audinių kultūrose slopinti SARS-CoV-2 proliferaciją ir apsaugoti ląsteles nuo citopatinio poveikio [16]. Tarp tirtų vaistų buvo ir preparatai, kuriais gydoma PL bei kiti judejimo sutrikimai: amantadinas, karbidopa, benserazidas, levodopa, pramipeksolis, primidonas. Vis dèlto, nuo SARS-CoV-2 citopatinio efekto audinių kultūroje ląsteles geriausiai apsaugojo šie 5 vaistai: prieš žmogaus imunodeficito virusą veikiantys preparatai lopinaviras ir nelfinaviras, steroidas loteprednolio etabonatas, imunosupresantas rapamicinas ir priešuždegiminis bei priešnavikinis vaistas cefarantinas. Didžiausiu antiSARS-CoV-2 potencialu ir sinergistiniu poveikiu iš šiu vaistų pasižymejo cefarantinas ir nelfinaviras. Nelfinaviras suriša pagrindinę viruso proteazę ir inhibuoja SARS-CoV-2 replikaciją. Cefarantinas - augalinis alkaloidas, izoliuojamas iš Kinijoje augančios Stephania cepharantha Hayata, prisijungia prie SARS-CoV-2 spyglio ir taip slopina viruso patekimą i ląsteles. Idomu, kad cefarantinas, multifaktorinis preparatas, pasižymi priešuždegiminiu poveikiu ir selektyviai inhibuoja $\beta$-amiloido oligomerų prisijungimą prie efrino-B receptorių 2 bei mažina aktyvuotų B-limfocitų baltymų komplekso NFkB ekspresiją (angl. Nuclear factor kappa-light-chain-enhancer of activated $B$ cells) [17]. $\beta$-amiloido oligomeras - viena svarbiausių molekulių Alzheimerio ligos patogenezèje. Baltymų kompleksas NFkB laikomas potencialiu priešuždegiminio Alzheimerio ligos gydymo taikiniu, o augalų kilmès derivatai, kurie interferuoja su NFאB, - potencialiai šios demencijos gydymui tinkamais vaistais [17]. Duomenų, kad cefarantinu galima būtų gydyti PL ar kitus judèjimo sutrikimus, aptikti nepavyko. Antikoronavirusines lopinaviro, ritonaviro, favipiraviro, remdesiviro, chlorokvino, makrolidų, cefarantino ir nelfinaviro bei kitų preparatų savybes mokslininkai tiria toliau, kai kuriuos iš jų ex juvantibus jau naudoja sunkiems COVID-19 ligoniams gydyti.

Žinoma, judejjimo sutrikimų tematikos kontekste mus labiausiai domina, ar kurie nors Parkinsono, Hantingtono ir kitoms ligoms gydyti skiriami vaistai galètų pasižymėti realiu anti-SARS-CoV-2 potencialu. E. Brison su kolegomis $2014 \mathrm{~m}$. paskelbè, kad adamantano derivatas bananinas pasižymi priešvirusiniu poveikiu prieš SARS koronavirusą, blokuodamas fermentą helikazę, kuri yra gyvybiškai svarbi viruso nukleino rūgšties replikacijai [18]. Klinikinejje praktikoje, gydant neurologinius pacientus, taikomi du adamantano derivatai - amantadinas ir memantinas, $\mathrm{ku}$ rie praeina per kraujo ir smegenų barjerą, blokuodami NMDA receptorius mažina padidejjusị neuronų dirglumą ir užkerta kelią ekscitotoksiškumui bei veikia neurologinius simptomus. Amantadinas buvo sukurtas kaip priešvirusinis preparatas prieš gripo A virusą, nes, blokuodamas matrikso-2 (M2) baltymo jonų kanalus, sutrukdo virusui netekti savo dangalo šeimininko ląstelių endosomose. Memantinas gali slopinti žmogaus koronaviruso OC43 (HCoV-OC43) baltymą E panašiai, kaip amantadinas veikia M2 proteiną, arba inhibuoti viruso helikazę kaip bananinas [18]. Amantadino ir memantino kaina nèra didelè, o saugumas yra gerai ištirtas. Šių vaistų dažniau vartoja vyresnio amžiaus asmenys dèl pažengusių neurodegeneracinių ar kitų ligų, priklausantys COVID-19 rizikos grupei. JAV Majo klinikos mokslininkai, Parkinsono ligos ekspertai P. W. Tipton ir Z. K. Wszolek kviečia medicinos bendruomenès atstovus atkreipti dėmesi i šiuc preparatų savybes ir kuo greičiau retrospektyviai ištirti ju prevencini ar (ir) terapini potencialą, kovojant su SARS-CoV-2 [19].

SARS-CoV-2 patekimas į šeimininko ląstelę priklauso ne tik nuo viruso spyglio baltymo $S$ prisijungimo prie ląstelès, bet ir nuo to, kaip spyglio baltymus skaldo šeimininko endosomu proteazès - katepsinai B ir L, atpalaiduodami viruso glikoproteiną prieš susiliejimą su šeimininko ląstelès membrana. Nustatyta, kad būtent katepsinas L yra ypač svarbus Ebolos ir SARS-CoV invazijai. Manoma, kad genetinis šios proteazès polimorfizmas galètų nulemti viruso sklidimo organizme pobūdị, kitaip tariant, sąlygoti imluma viruso sukeltai infekcinei ligai. Vadinasi, kovojant su COVID-19, vienu iš terapinių taikinių galètų tapti katepsino L geno ekspresiją slopinantis preparatas. Vanda Pharmaceuticals kompanijos mokslininkẻ S. P. Smieszek su bendraautoriais neseniai paskelbė katepsino L geno reguliacijos tyrimo rezultatus: ištyrus 466 vaistus, nustatyta, kad vienas iš stipriausiai blokavusių katepsino L geno ekspresiją - tropizmu lizosomoms pasižymintis amantadinas, kuris šiuo mechanizmu nutraukè viruso gebejjimą replikuotis padedant šeimininko lizosomų proteazèms [20]. Šio genetinio tyrimo autoriai taip pat suformulavo hipotezę, kad amantadinas galètų mažinti SARS-CoV-2 kiekị infekuotame organizme, slopindamas viruso replikaciją ir infektyvumą ir taip leisdamas pasiekti geresnę COVID-19 išeiti. Norint patvirtinti arba paneigti šias virusologų [18], neurologų [19] ir genetikų bei farmakologų [20] prielaidas apie amantadino ar (ir) memantino anti-SARS-CoV-2 potencialą, būtini skubūs specializuoti klinikiniai tyrimai.

\section{VAISTU, SKIRIAMŲ COVID-19 GYDYTI, POTENCIALUS ŠALUTINIS POVEIKIS JUDĖJIMO SUTRIKIMŲ KONTEKSTE}

Medikamentiniai judejjimo sutrikimai, vartojant ištirtų ir rinkoje jau registruotų vaistų, kurių šiuo metu skiriama pacientams su COVID-19, pasitaiko retai ir nebūna nei izoliuoti, nei labiausiai trikdantys funkciją: $\geq 1 / 1000-<1 / 100$ asmenų, vartojant lopinaviro / ritonaviro, gali vystytis tremoras [21], vartojant nelfinaviro - hiperkinezès [22]. Gydant hidroksichlorokvinu, pacientams gali atsirasti ekstrapiramidinių sutrikimų, kurių dažnis - nežinomas (aprašyta distonija, diskinezijos, tremoras) [23]. Cefarantinas, remiantis jo beveik $50 \mathrm{~m}$. siekiančia vartojimo Japonijoje patirtimi, laikomas gerai toleruojamu vaistu [24]. Nėra aprašyta svarbiausių PL ir kitiems judejimo sutrikimams gydyti skirtų vaistų nepageidaujamos sąveikos su šiandien nuo koronaviruso vartojamais preparatais. Lopinaviro ir ritonaviro negalima vartoti kartu su kvetiapinu, kuriuo gydomos parkinsoniniais sindromais sergančių as- 
menų psichozės, kadangi lopinaviras ir ritonaviras (kaip ir nelfinaviras) slopina CYP3A, taigi, padideja kvetiapino koncentracija plazmoje ir, pasireiškus toksiniam poveikiui, pacientą gali ištikti grèsmingi širdies ritmo sutrikimai ar koma [21].

\section{PANDEMIJOS İTAKA JUDE்JIMO SUTRIKIMŲ TURINČIAM PACIENTUI, NESERGANČIAM COVID-19}

Pandemija ir jos efektas socialinei visuomenès organizacijai itin neigiamai veikia visomis lètinèmis ligomis sergančių vyresnio amžiaus asmenų gyvenimo kokybę ir sveikatos rodiklius [12, 13], pasunkina komplikacijų diagnostiką ir gydymo optimizavimo galimybes. Ir sveikiems, ir sergantiesiems kyla stresas, panika, dèl karantino nukenčia galimybė aktyviai judèti, dirbti, sportuoti, tęsti pomėgius, religinę praktiką, planuotas paslaugas. Pacientams, sergantiems PL, distonijomis, Hantingtono liga ir kitais judèjimo sutrikimais, staiga atidedami planuoti apsilankymai pas gydytojus. Šios pažeidžiamos grupès asmenims tai sukelia daug nerimo, sumišimo, netikètų klausimų ir problemų. I Romoje esančią Tor Vergata universiteto ligoninės PL kliniką per 12 pirmų su COVID-19 susijusio karantino dienų paskambino ar (ir) parašè 162 sunerimę pacientai ir slaugytojai: $46 \%$ nerimavo ir teiravosi dèl medicinos paslaugų prieinamumo (tyrimų, neurologo vizitų, vaistų išrašymo, reabilitacijos procedūrų), $28 \%$ nurodè staigų su PL susijusị būklès pablogèjimą, $17 \%$ (dauguma jaunesnio amžiaus ir sergantys pradine ar lengvesne liga) domėjosi ryšiu tarp PL ir COVID-19, 8 \% informavo apie staigius interkurentinius sveikatos būklès pasikeitimus [25]. Iš tų pacientų, kurie nurodè staigų būklès pablogejjimą, $50 \%$ asmenų pasunkèjo motorinė būklè (tremoras, rigidiškumas, eisenos sutrikimai), $25 \%$ sustiprejo nerimas, $18 \%$ išsivystė ar pablogejo neuropsichiatriniai sutrikimai - haliucinozè, ažitacija, psichozès, o 16 \% skundèsi kitais nemotoriniais simptomais (nuovargiu, skausmu ir pan.). Dẻl būklès pablogèjimo 52,3\% pacientų teko koreguoti gydymą nuotoliniu būdu: 33,3\% - dopaminerginius vaistus, 41,7 \% anksiolitikus (pridèti benzodiazepinų), $25 \%$ - pridèti ar padidinti neuroleptiko dozę. Tarp $8 \%$ pacientų, kurie pranešè apie staigius sveikatos būklès pasikeitimus dèl lydinčių ligų, nė vienam nebuvo patvirtintas COVID-19 (nors $23,1 \%$ jis buvo ịtartas); šios grupés pacientų motorine būklè buvo sunkesnè, PL stažas - ilgesnis. Tyrimo autoriai [25] apibendrino du svarbiausius PL sergančių asmenų poreikius pandemijos metu: 1) tiksli ir operatyvi informacija, nes optimali komunikacija mažina pacientų stresą; 2) medicininès pagalbos tęstinumas - net ir redukavus jo apimtis, nes būtina dinamikoje kartotinai vertinti judejjimo sutrikimo sunkumą, kognityvinę būklę ir peržiūrèti gydymo schemas. Kontaktinių vizitų vietą užima teleneurologija tai nuotolinės telekonsultacijos ar (ir) elektroniniai laiškai, tačiau, norint bent iš dalies įvertinti motoriką, būtų geriausia organizuoti vaizdo konsultacijas. Vaizdo konsultacijos ir elektroniniai laiškai taip pat svarbūs tęsiant ir atnaujinant pacientų mokymą (apie vaistų vartojimo režimą, mitybą, nemedikamentines judejjimo gerinimo priemones, dienoraščių pildymą, savistabą dẻl impulsų kontrolès sutrikimų ir mieguistumo dieną, suvokimo sutrikimų), nes gydymo efektas tiesiogiai priklauso nuo to, kaip pacientas supranta ir laikosi pateiktų instrukcijų, o telefoninès konsultacijos, ypač bendraujant su klausos, regos ar kognityvinių sutrikimų turinčiu asmeniu, šios pridėtinès vertės užtikrinti negali. Pastaraisiais metais kuriami ir tobulinami nuotoliniai išmanieji judejjimo sutrikimų pacientų būklès stebėsenos prietaisai. Jų platesnis ir greitesnis įdiegimas palengvintu asmenų sveikatos priežiūrą pandemijos metu, atsižvelgiant ị prognozuojamą SARS-CoV-2 sukeltos ligos aktualumą. Tarptautinė Parkinsono ligos ir judẻjimo sutrikimų draugija pateikè specializuotas laipsniško telemedicinos diegimo nuorodas, kurios yra naudingos kiekvienai su šia pacientų grupe dirbančiai klinikai [26]. Teleneurologijos vystymas yra svarbus ịvairiomis lètinèmis neurologinėmis ligomis sergančių asmenų stebėsenai ir gydymo kontrolei tiek pandemijos metu, tiek ir suvaldžius naujojo koronaviruso plitimą, tačiau tiksli naujo judejjimo sutrikimo atvejo diagnozė gali būti nustatoma tik tiesioginio kontakto su ligoniu metu, pasitelkiant ịprastas neurologinès apžiūros priemones.

Deja, pandemija ne tik paveikè pacientų medicinines paslaugas, bet ir pristabdè mokslo plètrą, biologinių žymenų bei ligas modifikuojančio gydymo klinikinius tyrimus, taip pat edukacijos procesą, nukreipdama visą dèmesị daugiausiai ị COVID-19. Tenka šią netekti priimti kaip neišvengiamą, tikintis, kad visų specialybių medikų mobilizuota kova su naujuoju koronavirusu baigsis pergale ir nutrauks laikiną stagnaciją kitose srityse.

\section{REKOMENDACIJOS IR PRIORITETAI COVID-19 PANDEMIJOS METU, SERGANT PARKINSONO LIGA IR JUDE்JIMO SUTRIKIMAIS}

Pasaulinė sveikatos organizacija pateikè su naujojo koronaviruso pandemija susijusias infekcijos valdymo rekomendacijas [27], kurias iš esmès pakartojo ir ịvairios specializuotos medicininès organizacijos. Su pacientų saugumu susijusios nuorodos (socialinè distancija, kontaktų ribojimas, higienos priemonès, tyrimas dèl SARS-CoV-2) yra bendros, nesiskiria sergant PL, Hantingtono liga, Vilsono liga, distonijomis, ataksijomis, tremorais ar kitomis hiperkinezėmis ir labiau priklauso nuo asmenų amžiaus bei lydinčių ligų, taip pat nuo konkrečioje šalyje pritaikytų priemonių. Vis dèlto, Tarptautinė Parkinsono ligos ir judèjimo sutrikimų draugija pateikè struktūrizuotas rekomendacijas, skirtas sergantiesiems PL ir kitais judejjimo sutrikimais, kurių siūlo laikytis COVID-19 pandemijos metu [28]:

- griežtai laikytis globalių, bendrai populiacijai taikomų socialinių kontaktų ribojimo priemonių;

- atšaukti ar atidèti planine tvarka teikiamas stacionarias paslaugas, taip pat ir giliosios pamato branduo- 
lių stimuliacijos procedūrą, stengiantis sumažinti galimybę užsikrèsti SARS-CoV-2 stacionare;

- ambulatorines konsultacijas atlikti nuotoliniu būdu, nebent būtina tiesiogiai apžiūrèti pacientą, norint koreguoti giliųjų pamato branduolių stimuliatoriaus programą ar bateriją, duodenalinės levodopos pompos veiklą, atlikti būtinas botulino toksino injekcijas, užtikrinant adekvačias apsaugos priemones;

- motorinès būklès, motyvacijos, nuotaikos gerinimui rekomenduojama skatinti pacientus naudoti namuose prieinamas sporto priemones ar (ir) žaisti virtualios realybės žaidimus;

- diagnozavus COVID-19, būtina užtikrinti tolesnị anksčiau judejjimo sutrikimui gydyti skirtu vaistu vartojimą (ypač adekvačias levodopos ir periferinès dekarboksilazės inhibitoriaus dozes), kad būtų išvengta sustiprejjusio rigidiškumo, kontraktūrų, gyvybinès plaučių talpos ir maksimalaus iškvèpimo tūrio sumažejimo.

Taigi, šiuo metu vis dar kaupiame žinias apie SARS-CoV-2, jo savybes ir sukeliamos ligos ypatumus, todèl suprantama, kad informacija gali labai greitai keistis.

\section{Literatūra}

1. Asadi-Pooya AA, Simani L. Central nervous system manifestations of COVID-19: a systematic review. J Neurol Sci 2020; 413: 116832. https://doi.org/10.1016/j.jns. 2020.116832

2. Rothan HA, Byrareddy SN. The epidemiology and pathogenesis of coronavirus disease (COVID-19) outbreak. J Autoimmun 2020; 109: 102433. https://doi.org/10.1016/ j.jaut.2020.102433

3. Desforges M, Le Coupanec A, Dubeau P, et al. Human coronavirus and other respiratory viruses: underestimated opportunistic pathogens of the central nervous system? Viruses 2020; 12(1): 14. https://doi.org/10.3390/v12010014

4. Mao L, Wang M, Chen S, et al. Neurological manifestations of hospitalized patients with COVID-19 in Wuhan, China: a retrospective case series study. MedRxiv 2020. https://doi.org/10.1101/2020.02.22.20026500

5. Fazzini E, Fleming J, Fahn S. Cerebrospinal fluid antibodies to coronavirus in patients with Parkinson's disease. Mov Dis 1992; 7(2): 153-8. https://doi.org/10.1002/mds.870070210

6. Lechien JR, Chiesa-Estomba CM, De Siati DR, et al. Olfactory and gustatory dysfunctions as a clinical presentation of mild-to-moderate forms of the coronavirus disease (COVID-19): a multicenter European study. Eur Arch Otorhinolaryngol 2020. https://doi.org/10.1007/s00405020-05965-1

7. Schaeffer E, Postuma RB, Berg D. Prodromal PD: a new nosological entity. Prog Brain Res 2020; 252: 331-56. https://doi.org/10.1016/bs.pbr.2020.01.003

8. Joglar B, Rodriguez-Pallares J, Rodriguez-Perez AI, Rey P, Guerra MJ, Labandeira-Garcia JL. The inflammatory response in the MPTP model of Parkinson's disease is mediated by brain angiotensin: relevance to progression of the disease. J Neurochem 2009; 109(2): 656-69. https://doi.org/ 10.1111/j.1471-4159.2009.05999.x
9. Antonini A, Leta V, Teo J, Chaudhuri KR. Outcome of Parkinson's disease patients affected by COVID-19. Mov Disord 2020. https://doi.org/10.1002/mds.28104

10. Nataf S. An alteration of the dopamine synthetic pathway is possibly involved in the pathophysiology of COVID-19. J Med Virol 2020. https://doi.org/10.1002/jmv.25826

11. Van Wamelen DJ, Leta V, Johnson J, et al. Drooling in Parkinson's disease: prevalence and progression from the Non-motor International Longitudinal Study. Dysphagia 2020. https://doi.org/10.1007/s00455-020-10102-5

12. Prasad S, Holla VV, Neeraja K, et al. Parkinson's disease and COVID-19: perceptions and implications in patients and caregivers. Mov Disord 2020. https://doi.org/10.1002/ mds. 28088

13. Helmich RC, Bloem BR. The impact of the COVID-19 pandemic on Parkinson's disease: hidden sorrows and emerging opportunities. J Park Dis 2020; 10(2): 351-4. https://doi.org/ 10.3233/JPD-202038

14. Richardson S, Hirsch JS, Narasimhan M, et al. Presenting characteristics, comorbidities, and outcomes among 5700 patients hospitalized with COVID-19 in the New York city area. JAMA 2020; 323(20): 2052-9. https://doi.org/ 10.1001/jama.2020.6775

15. Liang WH, Guan WJ, Li CC, et al. Clinical characteristics and outcomes of hospitalized patients with COVID-19 treated in Hubei (epicenter) and outside Hubei (non-epicenter): a nationwide analysis of China. Eur Respir J 2020; 55: 2000562. https://doi.org/10.1183/13993003. $00562-2020$

16. Ohashi H, Watashi K, Saso W, et al. Multidrug treatment with nelfinavir and cepharanthine against COVID-19. bioRxiv 2020.04.14.039925. https://doi.org/10.1101/ 2020.04.14.039925

17. Seo EJ, Fischer N, Efferth T. Phytochemicals as inhibitors of $\mathrm{NF}-\kappa \mathrm{B}$ for treatment of Alzheimer's disease. Pharmacol Res 2018; 129: 262-73. https://doi.org/10.1016/j.phrs. 2017.11.030

18. Brison E, Jacomy H, Desforges M, Talbot PJ. Novel treatment with neuroprotective and antiviral properties against a neuroinvasive human respiratory virus. J Virol 2014; 88(3): 1548-63. https://doi.org/10.1128/JVI.02972-13

19. Tipton PW, Wszolek ZK. What can Parkinson's disease teach us about COVID-19? Neurol Neurochir Pol 2020; (54): 204-6. https://doi.org/10.5603/PJNNS.a2020.0039

20. Smieszek SP, Przychodzen BP, Polymeropoulos MH. Amantadine disrupts lysosomal gene expression: a hypothesis for COVID 19 treatment. Int J Antimicrob Agents 2020; 106004. https://doi.org/10.1016/j.ijantimicag.2020.106004

21. European Medicines Agency's official website. Summary of European Public Assessment Report for Kaletra. Available from: https://www.ema.europa.eu/en/medicines/human/ EPAR/kaletra [Žiūrèta: 2020-05-11].

22. US Food and Drug Administration's official website. Viracept. Available from: https://www.accessdata.fda.gov/ drugsatfda_docs/label/2011/020778s035,020779s056, 021503s017lbl.pdf [Žiūrèta: 2020-05-11].

23. Valstybinès vaistų kontrolès tarnybos portalas. Plaquenil: preparato charakteristiku santrauka. Available from: https://vapris.vvkt.lt/vvkt-web/public/medications/view/ 27522 [Žiūrèta: 2020-05-11].

24. Bailly C. Cepharanthine: an update of its mode of action, pharmacological properties and medical applications. Phytomedicine 2019; 62: 152956. https://doi.org/10.1016/ j.phymed.2019.152956 
25. Schirinzi T, Cerroni R, Di Lazzaro G, et al. Self-reported needs of patients with Parkinson's disease during COVID-19 emergency in Italy. Neurol Sci 2020; 41: 1373-5. https://doi.org/10.1007/s10072-020-04442-1

26. International Parkinson Disease and Movement Disorders Society's official website. Telemedicine in your movement disorders practice. Available from: https://www.movementdisorders.org/MDS/About/ Committees-Other-Groups/Telemedicine-in-YourMovement-Disorders-Practice-A-Step-by-Step-Guide.htm [Žiūrèta: 2020-05-11].

27. World Health Organization's official website. Coronavirus disease (COVID-19) pandemic. Available from: https://www.who.int/emergencies/diseases/novelcoronavirus-2019 [Žiūrèta: 2020-05-11].

28. Papa SM, Brundin P, Fung VSC, et al. Impact of the COVID-19 pandemic on Parkinson's disease and movement disorders. Mov Disord 2020; 35(5): 711-5. https://doi.org/ 10.1002/mds. 28067

\section{R. Kaladytė Lokominienè}

\section{PARKINSON'S DISEASE AND OTHER MOVEMENT DISORDERS IN THE CONTEXT OF THE SARS-COV-2 PANDEMIC}

\section{Summary}

Severe acute respiratory syndrome coronavirus-2 (SARS-CoV-2) is able to invade the human nervous system and can cause headache, nausea, vomiting, febrile seizures, encephalopathy, encephalitis, ataxia or psychiatric disorders, as well as quantitative disturbances of smell and taste which are observed both during the course of Parkinson's disease and other alpha-synucleinopathies, only in slowly progressive and irreversible manner. The penetration of SARS-CoV-2 into the brain damaged by Parkinson's disease can enhance the clinical burden of movement disorder and increase the deficit for substitutional dopaminergic therapy. To date, there are no randomised controlled trials of COVID-19 outcomes in cases of Parkinson's disease and other movement disorders though patients of this category can be more vulnerable because of rigidity or dissinergy of respiratory musculature, diminished cough reflex, impaired swallowing, and chronic dyspnea. Indirect aggravating factors during the pandemic include stress, self-isolation, anxiety, and prolonged hypomobility which have a negative impact on the clinical burden of movement disorder and predispose weakened immune reactions. The compulsory limitations of contacts with physicians and relatives make cognitively impaired patients more prone to violations of medication regimen. In this case, teleneurology is a perspective mode of medical care for patients with movement disorders during the pandemic. Amantadine and memantine are presumed to have some anti-SARS-CoV-2 potential but this assumption should be confirmed in clinical trials. International Parkinson Disease and Movement Disorders Society has published recommendations and priorities for patients with Parkinson's disease and other movement disorders during the COVID-19 pandemic which state that all measures of social distancing currently in place for the general population almost globally must be strictly and carefully practiced, direct consultations must be held in exceptional cases (e.g., for adjusting or checking deep brain stimulation programming, battery failure, levodopa duodenal pump treatments, botulinum toxin therapy), and patients should be encouraged to use sports equipment available at home and /or play virtual reality games. In case COVID-19 is diagnosed, the physician must ensure the maintenance of previous medications, especially adequate doses of levodopa/peripheral decarboxylase inhibitor to avoid rigidity with contractures and respiratory impairment with reduced vital capacity and peak expiratory flow.

Keywords: Parkinson's disease, movement disorders, SARS-COV-2, pandemic, COVID-19.

Gauta:

20200516
Priimta spaudai: 20200607 